\title{
Role of Finance on the Growth of Small and Medium Scale Enterprises in Edo State of Nigeria
}

\author{
Robinson Osarumwense Owenvbiugie* \\ Department of Vocational and Technical Education, Faculty of Education, University of Benin, Benin City. Nigeria \\ Email: rowenvbiugie@gmail.com
}

Doi:10.5901/jesr.2015.v5n1p241

Prof. Victor Imuentinyan Igbinedion

Department of Vocational and Technical Education, Faculty of Education, University of Benin, Benin City. Nigeria

\begin{abstract}
The study determined the role of finance on the growth of small and medium scale enterprises in Edo State, Nigeria. One research question was raised and answered with descriptive statistics of mean and standard deviation. The study adopted a survey research design. A sample of 122 respondents was used for the study. Cronbach Alpha was used to compute the reliability of the instrument and yielded 0.89. The data collected revealed that SMEs growth was hindered as result of inability to access funds from financial institutions as aa result of stringent policies required by banks and other financial institutions. Based on these findings, it was recommended that necessary financial assistance should be given to the sector by government and other stakeholders in order to accelerate the growth of SMEs in the rural communities to reduce the current unemployment as well as reducing the rural-urban migration.
\end{abstract}

Keywords: SME, Finance, Access, Growth, and Unemployment.

\section{Introduction}

Finance is the life wire of any economy, whether developed or developing. Though human resources are the tools that propel any economic endeavour, but finance is very prominent after human resources. Finance is also known as capital, credit and so forth. Finance is to commercial pursuit as blood is to the human body. Finance is important to the survival and growth of SME, so it is to the small and medium scale enterprises or industry.

The rate of unemployment in Nigeria is one of the highest in the world which is at 24 per cent; and over 50 per cent of the youths in the urban areas are unemployed (Agboola, 2013). The situation has assumed a worrisome dimension of economic and social crises as there has arisen a relationship between rising criminality and unemployment. This is the more reason why those at the leadership positions in the country should urgently do something to increase the support for SMEs and business start-up through capacity building and funding as finance is very vital to the SMEs. In Nigeria, the small and medium enterprises are found wanting probably because most of them cannot access loans for their operations and growth. This may be due to institutional impediments posed by financial houses, including the Central Bank of Nigeria (CBN).

The SMEs have been variously referred to or conceptualised in terms of the number of employees, or the amount of capital invested in it or the turn over. Other concepts in use include relative size, ownership, type of industry, operational environment. These concepts are used due to the scale or level the SMEs are placed in an economy. However, almost the same value or category of items comprise the various concepts in different economic terrains. The National Council of Industry (1996) redefined the small scale enterprises as those enterprises with total cost including working capital but excluding cost of land of above N1 million and having manpower strength (that is, labour size) of 11 and 35 workers. Medium scale enterprises were defined as those having labour strength of between 36 and 100 workers and total cost including working capital but excluding cost of lands of above N40 million.

In Nigeria's Third National Development Plan, a small scale enterprise was defined as a manufacturing concern that employs less than ten people and whose investment on machinery and equipment do not exceed N600,000.00. As Todaro and Smith (2009), put it development in all societies must have at least three objectives - to increase the availability and widen the distribution of basic life -sustaining goods, to raise levels of living and the expansion of the range of economic and social choices available to individuals and nations.

Like other sectors of the economy, the roles of the SMES in the economic and social development of the country 
are legion. Among the roles are: employment creation, poverty reduction, skill acquisition, supply of goods and services, rural development, encouragement of entrepreneurial development and industrial development. The SMEs, for them to be the major fulcrum of economic growth and development of the country, must be adequately financed. Financial problem is one of the major causes of business failures. If the SMEs are inadequately financed there is every tendency that many of them may not survive. If there is no adequate fund to start a business, the entrepreneur will not be able to afford the facilities and personnel that are required to start up the business properly. The hope of a thriving small and medium enterprises sector in Nigeria may be dashed, if the view of the Central Bank of Nigeria Governor is anything to go by. For many years, the small and medium enterprises have been struggling for meaningful existence to no avail. Successive administrations in the country have only made rhetoric of their commitment to the sector. This is in spite of the fact that hundreds of millions of naira were purportedly loaned out for the scheme by commercial banks in the country annually. However, this is not to say that there were no previous attempts made to finance the sector in the country.

Some of the previous attempts made at financing the SMEs include:

The Nigeria Industrial Development Bank (NIDB), Nigerian Bank for Commerce and Industry (NBCl), the National Economic Reconstruction Fund (NERFUND), and the Small Scale Industry Credit Scheme (SSCICS). All these financial programmes were made to encourage the SMEs for possible growth and development, and by extension, for economic development of the country. However, these financial institutions have been merged and it is now known as the Bank of Industry which was established in 2001. This signaled the hope for the growth of various business enterprises and the small and medium enterprises in particular. The main objectives of the bank include:

(a) The provision of financial assistance for the establishment of large, medium and small projects

(b) The expansion, diversification and modernization of existing enterprises; and

(c) The rehabilitation of ailing industries.

The Bank is wholly owned and financed by the federal government and has its equity in the bank through its agencies, the ministry of finance $-59.54 \%$, and the CBN $-40.36 \%$. At its inception, the Bank had a total capital base of N50 billion for its operations. This gesture was a noble one as far as Nigerians and those in the real sector were concerned, given the global advocacy for the development of the economy through the empowerment of the SMEs. The Bank of Industry requires the following to access its loans:

(i) Photocopy of certificate of incorporation

(ii) Certified true copy of memorandum and articles of association for CA02.5 (C02) and form CAC2.3 (C07) of the company

(iii) Three years most recently audited accounts in the case of existing businesses

(iv) Report of feasibility study (2 copies)

(v) Land and building documents and approved building plan

(vi) Bill of quantities or contractors estimate/valuation report on building as applicable

(vii) Satisfactory tenancy agreement long enough to cover the tenure of Bol's facility in respect of suitable rented property

(viii) Proforma invoice for items of machinery and equipment from the source indicated in the feasibility

(ix) Price and source of raw materials

(x) Tax clearance certificate of the company and two directors for the last three years

(xi) Eight recent passport photographs of each of the two directors and the company secretary

(xii) Photocopy of international passport or driver's licence of the two directors. This plethora of requirements probably may have hindered small scale business operators from accessing the required funds for their business startup.

As other similar policies and programmes were concerned, implementation is the bane of Nigeria's numerous policies. The Bank of Industry, in 2004 barely three years at inception was bedeviled with problems militating against its statutory obligations to the SMEs and real sector. As at June 30,2004, out of the N50 billion promised to be placed in the coffers of the Bank, only N5.4 billion was the only loanable funds in its coffer representing only $10.8 \%$ of the publicized N50 billion whereas a total loan applications of 594 valued at N130 billion was received (Famoofo, 2004). As part of its functions to ameliorate the challenges of accessing credit for the development of the SME sector, the federal government, through the Bank of Industry developed a counterpart funding scheme with some state governments. The scheme generated a funding pool of about N9 billion for the growth and development of the SME sector.

Besides finance or access to credit, the scheme is also aimed at harnessing the enormous opportunities in the SME sector in order to have an all-inclusive economic growth through skills acquisition, entrepreneurship training, employment and wealth creation (Afolabi, 2013). The Bank of Industry is not the only government institution established 
to finance the SMEs. There is also the Micro, Small and Medium Enterprises Development Fund (MSMEDF) which earmarked a fund of N220 billion, with a minimum of 60\% (N132 million) of the fund committed to providing financial services to women so as to address their peculiar financial exclusion problems. The main objectives of the fund are two, namely, social/development/grant (Agboola, 2013). Ten per cent of the fund was earmarked for administrative objectives in the following categories - managing agent's operational activities of three per cent (N3.96 b) and interest drawback programme of two per cent (N2.64b). For a microfinance bank or finance company to qualify for support from the fund, it is expected to meet the following requirements as stipulated by the Central Bank of Nigeria examination report:

(a) Compliance with regulatory capital

(b) Compliance with prevailing prudential ratios thus:

(i) Liquidity $20 \%$ (ii) capital adequacy ratio, $10 \%$ (iii) adjusted capital to net credit ratio and micro credit to other loans ratio 80:20

(c) Average deposit growth rate of 20 per cent per annum

(d) Favourable profit trend for three years

(e) Risk management framework acceptable to the regulators

(f) Corporate governance culture acceptable to the regulators

Another approach aimed at financing the SMEs in the past was the Community Banks. By Decree No. 46 of 1992, community banks were established with a minimum capital of N250,000.00. A community bank, according to the Decree, is a "self sustaining institution owned and managed by a community or a group of communities for the purpose of providing credit, banking and other financial services to its members largely on the basis of their self-recognition and credit worthiness." As part of its mandate to serve the people at the grass roots, of which SME is one, it was expected that the Community Development Associations (CDAs) held 30 per cent of the total share capital. Another criterion and determinant of setting up of community banks was its geographical location. The Decree stipulated that community banks be sited near a market. It required its operations be restricted to specified geographical area thus making it more relevant to small and medium scale economic activities (Orji, 2004).

However, due to the inactiveness of most of the community banks, the federal government, on $15^{\text {th }}$ December, 2005, launched the Microfinance Bank Policy, Supervisory and Regulatory Framework. The microfinance banks took over the functions of the community banks. Microfinance is the rendering of financial services to the economic active poor and low income group. Broadly defined, it is also meant to cover both small loans to the poor, often, but not exclusively based on group liability, as well as small loans to micro, small and medium enterprises. This type of financial services emerged as an innovative form of financial intermediation over the last 30 years. Before microfinance service was introduced into the Nigerian economy, it was obvious that only about 35 per cent of Nigerian economically active population had access to financial services and 65 per cent relied on the informal sector with less than half of rural households had access to formal financial and banking services. The Microfinance Policy was designed to boost the capacity of micro, small and medium enterprises towards economic growth and development through financial intermediation.

Among the primary objectives of the microfinance policy were: to make financial services accessible to a large segment of the potentially productive Nigerian population which otherwise would have little or no access to financial services; to promote synergy and mainstreaming of the informal sub-sector into the national financial system; enhance service delivery by microfinance institutions to micro, small, and medium enterprises and contribute to rural transformation. The microfinance banks are highly regulated by the Central Bank of Nigeria (CBN). Most of them are independent of government as they are privately owned and operated. Only few are owned and operated by governments. Some state governments embarked on the establishment of micro-credit scheme. For example the Delta State government gave loans to about 25,537 beneficiaries in her micro-credit scheme in 2009 (Aiwerie, 2009). The microfinance banks have been assisting to alleviate poverty and rendering financial services to the SMEs.

However, the microfinance banks have their problems which militate against giving robust financial services to the SMEs as it was envisaged at the inception of the policy. The problems include high interest rates, default in loan repayment by clients and beneficiaries of the banks, most of the banks are based in urban areas, and they are not much capitalized as they have poor financial bases. This is the reason there has been clamour for a special fund for microfinance services where microfinance banks can source for funds at very low interest rate.

Another credit scheme established to aid poverty reduction and the small and medium enterprises was the National Poverty Eradication Programme (NAPEP) under which the Conditional Cash Transfer Scheme (COPE) was launched. The scheme (COPE) was implemented with the support from the Millennium Development Goals (MDGs) office in collaboration with the Small, Medium Enterprises Development Agency (SMEDAN). In 2008, a grant of N1.06 
billion was released by the federal government (Ogbu, 2009). Whether this grant was actually utilized for the purpose it was meant to enable the masses participate in the process of economic development, is not known as the SMEs sector is still groaning in financial problems.

Some other financial measures were later put in place in recent years in order to encourage the SME sector. These measures include the introduction of the over-the-counter (OTC) market by the National Association of Securities Dealers (NASD) (Agboola, 2013). The introduction of this scheme is to assist SMEs seeking longer-term loans have access to long term credit. The OTC is not listed on the stock exchange market but is a decentralized market of securities where the operators trade over the telephone or electronic network, instead of physical trading floor, to access funds from the market. The OTC gives prominence to the SMEs because the sector is the bedrock of any economy.

The requirements needed to access the loan or credit from the OTC is to apply to raise funds through the initial public offer (IPO) before the company is admitted as a security for trading on the platform through any of the registered stock brokers on the Securities and Exchange Commission (SEC). However, the SEC would conduct a thorough check on the security to verify the growth and corporate governance status of the company in order to determine if the company is good for the consumption of the public.

In spite of all these financial policies and programmes aimed at assisting SMEs to move out of their financial quagmire, the same old song is on as they are still finding it hard to access credit for their operations. The financial problems include: Multiple taxation, difficulty in accessing credit, the financial institutions, including commercial banks, are very critical to national economic development, but they are not helping the SMEs. The current structure of lending to the Nigerian economy is such that the bulk of aggregate credit is channeled mainly towards financial market operations and oil traders to the neglect of the key aspects of the real economy such as the SMEs, amongst others.

An economy where interest rate hovers between 19 and 25 per cent per annum is not encouraging for the real sector much less for the SMEs which are managing to survive as most of them are not firmly rooted on ground. Borrowing from the commercial banks is herculean to the SMEs. Besides the interest rates of between 22 and 35 per cent, there are other charges which include administrative/management fee, concession fee, processing fee, and too many others. The manner the Nigerian Agricultural Credit and Rural Development Bank (NACRB) is structured and focused seems not to favourable for the SMEs as the its interest rate is capped at 8 per cent, while the cost of capital is more than 12 per cent. The bank does not also have the reach in terms of branches, neither does it have the capacity for lending, nor the information technology platforms and human resources requirement. The Bank does not even address the issue of how to get credit to the SMEs (Radwan, 2009).

\subsection{Purpose of the Study}

The purpose of the study was to determine the role finance plays in the growth of small scale and medium scale enterprises in Edo state.

\subsection{Significance of the Study}

The findings of this study will contribute to a body of knowledge and increase information in the area of loan assessment to small scale business owners. Therefore it will be of immense importance to small business operators, government, industrialists, and other stake holders in the industrial sub-sector.

\subsection{Research Question}

The following research question guided the study:

To what extent has finance hampered the growth of SMEs in Edo State?

\section{Methodology}

The survey research design was employed for this study. According to Leary (2010) a survey uses questionnaire, and interview to collect information about people's attitudes, beliefs, feelings, behaviours, and lifestyles. A survey is a descriptive study which seeks or uses the sample data of in an investigation to document, describe, and explain what is in existence on the present status of a phenomenon being investigated. A survey uses questionnaire and interview to collect information about people's attitudes, beliefs, feelings, behaviours, and lifestyles. It is designed to describe the characteristics or behaviours of particular population in a systematic and accurate fashion. This design was found most appropriate for this study because the study sought information from the respondents relative to their attitudes, beliefs, 
feelings, and behavior.

A total of 122 respondents formed the sample randomly selected for the study and a structured questionnaire was designed by the researchers on a Likert Type Scale. The questionnaire had two main sections. Section A dealt with demographic information of the respondents, while section B comprised of 21 item statements. The 5-point rating scale of Very Great Extent, High Extent, Great Extent; Low Extent and Very Low Extent with boundary limits of 4.50-5.00, 3.504.49, 2.50-3.49, 1.50-2.49, and 0.50-1.49 respectively

The questionnaire was validated by two experts in the Departments of Business Administration, University of Benin, Benin City. Nigeria

The reliability of the data collected was determined by using Cronbach Alpha method. This method was found more appropriate in that it takes care of the internal consistency of the instrument. The instrument was administered on 20 SMEs operators in Edo State who were not part of the sample used for the study. The value of the reliability obtained was 0.89 .

The questionnaire items were administered on 122 SMEs operators in the three senatorial districts of Edo State. The researchers personally administered some to the respondents, while two research assistants who were employed and trained for two weeks administered others. On the whole 122 copies of questionnaire were returned and used representing $100 \%$.

The data generated from the questionnaire were analyzed using mean and standard deviation to answer the research question.

\subsection{Decision Rule:}

The level of agreement and disagreement of each questionnaire item related to the research question was determined on the mean rating of the item interpreted, relative to real boundary limits of number.

$\begin{array}{ll}\text { Very Great Extent (VGE) } & 4.50-5.00 \\ \text { High Extent (HE) } & 3.50-4.49 \\ \text { Great Extent (GE) } & 2.50-3.49 \\ \text { Low Extent (LE) } & 1.50-2.49 \\ \text { Very Low Extent } & 0.50-1.40\end{array}$

\section{Results}

The results for the study were obtained from the research question answered.

Research Question:

To what extent has finance hampered the grwoth of SMEs in Edo State?

Table 3.1: Mean score and standard deviation of SMEs being hampered in developing rural communities in Edo State.

\begin{tabular}{|c|c|c|c|c|}
\hline \multicolumn{2}{|c|}{ S/N Statement in the Questionnaire: To what extent: } & \multirow{2}{*}{$\begin{array}{l}\text { Mean } \\
3.80\end{array}$} & \multirow{2}{*}{$\begin{array}{l}\text { SD } \\
1.25\end{array}$} & \multirow{2}{*}{$\begin{array}{l}\text { Decision } \\
\mathrm{HE}\end{array}$} \\
\hline 1. & Micro finance banks provide enough fund to finance SMEs & & & \\
\hline 2 & Does lack of fund affect SME in its operation & 2.30 & 1.1 & VGE \\
\hline \multirow[t]{2}{*}{3} & Entrepreneurs have enough collateral to obtain loans from & & & \\
\hline & Commercial banks & 2.33 & 1.07 & LE \\
\hline 4 & You have been able to comply with regulatory capital & 2.25 & 1.31 & LE \\
\hline 5 & You have been able to comply with liquidity ratio of $20 \%$ & 3.73 & 1.40 & HE \\
\hline 6. & You have been able to comply with capital a dequacy ratio of $10 \%$ & 3.68 & 1.03 & $\mathrm{HE}$ \\
\hline \multirow[t]{2}{*}{7} & You have been able to comply with average & & & \\
\hline & Deposit Growth of $20 \%$ per annum & 3.85 & 1.09 & $\mathrm{HE}$ \\
\hline \multirow[t]{2}{*}{8} & You have been able to comply with adjusted & & & \\
\hline & Capital to net credit ratio & 2.20 & 1.40 & LE \\
\hline 9 & Multiple taxation hinders the growth of SMEs & 3.72 & 1.3 & $\mathrm{HE}$ \\
\hline 10 & $\begin{array}{l}\text { Provision of certified copy of memorandum of } \\
\text { articles of Association is a problem in assessing loan }\end{array}$ & 3.88 & 1.04 & HE \\
\hline 11 & $\begin{array}{l}\text { Provision of } 3 \text { years most recent audited Account } \\
\text { hamperingloan assessing }\end{array}$ & 3.05 & 0.97 & GE \\
\hline 12. & Provision of feasibility study hinders loan assessment & 3.20 & 1.03 & GE \\
\hline 13. & Provision of land building document & 4.22 & 0.42 & $\mathrm{HE}$ \\
\hline 14. & Provision of Bill of Quantity & 4.70 & 0.47 & VGE \\
\hline 15. & Provision of satisfactory tenancy agreement & 4.78 & 0.42 & VGE \\
\hline 16. & Provision of tax clearance certificate. & 4.57 & 0.51 & VGE \\
\hline 17. & Provision of photo copy of intemational passport & 4.61 & 0.50 & VGE \\
\hline 18. & Evidence of source of raw materials & 4.87 & 0.34 & VGE \\
\hline 19. & Insistence of holding $30 \%$ of the total share capital & 4.83 & 0.39 & VGE \\
\hline 20 & The lending rate of between 22 to $30 \%$ hindering loan assessment. & 3.87 & 0.34 & $\mathrm{HE}$ \\
\hline 21 & Infrastructural problem is hamperingloan assessment & 3.78 & 0.42 & $\mathrm{HE}$ \\
\hline \multicolumn{2}{|c|}{ Grand Mean } & 3.80 & & \\
\hline
\end{tabular}


The data presented in table 3.1 showed that the responses of SMEs operators had their responses ranging from 2.20 to 4.87 with a grand mean of 3.80

The table further showed that the mean responses of SMEs operators for items 2, 14, 15, 16, 17, 18 and 19 indicated that the rate they are denied access to loans is of very great extent. Items $1,5,6,7,9,10,13$, 20, and 21 indicated that the rate they are denied access to loans to finance their operation is of high extent. Items 11 and 12 indicated that they rate they are denied access to loan for its operation is of great extent, while items 3,4 , and 8 indicated that the rate microfinance banks denied their access to loan is of low extent.

\section{Discussion of Results}

The result of the findings in all the item statements indicated that all the items have effect on SMEs securing loan from microfinance banks. This will in turn hamper their startup, growth and development. This position is in consonance with the work of Osoba (1987) who stated that financing strength is the main determinant of small and medium enterprises growth in developing countries. Aremu and Adeyemi (2011) claimed that most SMEs particularly in Nigeria die within their first five years of existence as a result of insufficient capital. Basil (2005) maintained that lack of focus, inadequate market research, over-concentration on one or two markets for finished products, lack of succession plan, inexperience, lack of proper book keeping, irregular power supply, infrastructural inadequacies (water, roads etc), lack of proper records or lack of any records at all, inability to separate business and family or personal finances, lack of business strategy, inability to distinguish between revenue and profit, inability to procure the right plant and machinery, inability to engage or employ the right caliber staff, and cut-throat competition hinder the growth of SMEs.

Osotimehin, Jegede, Akinlabi, and Olajide (2012) stated that financial constraints and lack of skill hamper the efficient performance of micro and small scale enterprises. Supporting this claim, Baumback (1983) contended that most of problems of small and medium scale enterprises are external to it. The researcher opined that access to financing and, lack of short, medium and long term capital, inadequate access to financial resources and credit facilities affect the growth of micro and small scale enterprises (MSEs). The researcher further observed that micro and small scale enterprises (MSEs) have serious financial problem in at least three respect of securing funds in small amount at rates comparables to those paid by large industries, building and manufacturing adequate financial reserves, securing long term equity capital, inflation, raising inflation rate, insufficient collaterals, inadequate record keeping and knowledge of the risks facing their business.

In consonance with the findings of this study Afolabi (2013) stated that a major gap in Nigeria's industrial development process in the past years has been the absence of a strong and virile small and medium enterprises subsector (SMEs) owing to financial constraints explained by high lending rates, high loan requirements and lack of viable entrepreneurial skills. He added that lack of adequate credit for SMEs, traceable to the reluctance of banks to extend credit to them among others; to poor documentation at project proposals as well as inadequate collateral by SME operators constitute one of the problems facing SMEs in Nigeria.

In support of the findings of this study Osamwonyi and Tafamel (2010) stressed that it seems clear that the problem with funding SMEs is not so much the sources of funds but the accessibility. Factors identified inhibiting funds accessibility by the SMEs are the stringent conditions set by financial institutions, the lack of adequate collateral and credit information, and the cost of accessing funds.

\section{Conclusion}

For the Nigeria economy to grow to attain the required socio-economic development, the SMEs must be given the necessary financial support to grow. The SMEs must be accorded the desired support of the government and financial institutions to grow rapidly to enable them contribute their quota to the development of Nigeria in general and Edo State in particular. Finance is the wheel in which business activities rotates. The financing of SMEs in Nigeria has been met with some impediments to access credit from microfinance banks and other financial institutions. These impediments have hindered the growth of SMEs in Nigeria.

To increase the viability and potency of this sub-sector, the government should increase to this sub-sector by way of removing dogmatic policies aimed at making it a lot easier for them to access loans without too stringent measures. By so doing, the sub-sector would then be in a better position to contribute more significantly to the overall development of the economy. 


\section{Recommendations}

For SMEs to be economically viable to contribute their quota to growth of Nigeria economy, the following recommendations are made based on the findings:

1. The necessary financial assistance should be given to the sector without stringent and unattainable collaterals.

2. The government should establish special fund where SMEs can access soft and cheap loan to finance their operations.

3. The loans given to SMEs should be at single digit interest rate.

4. The microfinance banks should be properly structured and funded to enable the SMES access credit.

\section{References}

Afolabi, B. (2013, December 8) How to Access SME Funds. The Nation, p.65

Afolabi, B. (2013, December 1) SMEs still battling with Teething problems, The Nation, p.66.

Afolabi, M.O. (2013). Growth effect of small and medium enterprises (SMEs) financing in Nigeria. Journal of African Macroeconomics Review, 3 (1): 193-199

Agboola, T. (2013, August 19) Jobs: SMEs to the rescue, The Nation, p. 37.

Agboola, T. (2013, December 9) Real Sector on the verge of death. The Nation, p.28.

Aiwerie, O. (2009, January 12). Delta empowers 25,537 through microcredit scheme. The Nation, pA8

Aremu, M.A. \& Adeyemi, S.L. (2011). Small and medium scale enterprises as survival strategy for employment generation in Nigeria. Journal of Sustainable Development, 4 (1): 200-206

Basil, A.N.O. (2005). Small and medium enterprises (SMEs) in Nigeria: Problems and prospects. PhD dissertation. St. Clements university, U.S.A.

Baumback, C.M. (1983).Problems of macro and small scale enterprises (MSEs). Basic small management. Price Hall Incorp, New Jersy Famoofo, B. (2004, August 12). Bol: Yearning for government "handout" New Age, p.24.

Leary, M.R. (2010). Descriptive research. Retrieved on $8^{\text {th }}$ May 2013 from http://wps.ablongman.com/ab_leary_resmethod_4/11/ 2989/765402

National Council of Industry (1996). An assessment of small-medium industries equity investment scheme implementation guidelines

Orji, J. (2004). CBN and Community Bank: Matters Arising, New Age, Thursday, August 12, 2004, p.23

Osoba, A.M. (1987). Small-scale enterprises in the development process, In Osoba, A.M (Eds.) Towards the development of small-scale industries in Nigeria. NISER, Ibadan, 8- 24

Osamwonyi, I.O. \& Tafamel, A.E. (2010). Options for sustaining small and medium scale enterprises in Nigeria: Emphasis on Edo state. International multi-disciplinary Journal of Ethiopia, 4 ( 3): 192-211

Osotimehin, K.O., Jegede, C., Oladije, O.T. and Akinlabi, B.H. (2012). An evaluation of the challenges and prospects of micro and small scale enterprises development in Nigeria. American International Journal of Contemporary Research, 2 (4): 174-185

Radwan, A. (2009). The impact of classroom orientation online student retention. Online Journal of Learning Administration, 12, 4.

Todaro, M.S. \& Smith, R. (2009): Economic Development, Pearson Education Limited, England 
